\title{
PCR-reverse blot hybridization assay in respiratory specimens for rapid detection and differentiation of mycobacteria in HIV- negative population
}

Qing Zhang ${ }^{1}$, Heping Xiao ${ }^{2^{*}}$ (D) and Liping Yan ${ }^{2^{*}}$

\begin{abstract}
Background: Rapid identification of pathogenic Mycobacterium species is critical for a successful treatment. However, traditional method is time-consuming and cannot discriminate isolated non-tuberculosis mycobacteria (NTM) at species level. In the retrospective study, we evaluated the clinical applicability of PCR-reverse blot hybridization assay (PCR-REBA Myco-ID) with clinical specimens for rapid detection and differentiation of mycobacterial species.
\end{abstract}

Methods: A total of 334 sputum and 362 bronchial alveolar lavage fluids (BALF) from 696 patients with mycobacterium pulmonary disease (MPD) and 210 patients with non-mycobacterium pulmonary disease used as controls were analyzed. Sputum or BALF were obtained for MGIT 960-TBC ID test and PCR-REBA Myco-ID assay. High resolution melt analysis (HRM) was used to resolve inconsistent results of MGIT 960-TBC ID test and PCR-REBA Myco-ID assay.

Results: A total of 334 sputum and 362 BALF specimens from 696 MPD patients (292 MTB and 404 NTM) were eventually analyzed. In total, 292 MTBC and 436 NTM isolates (mixed infection of two species in 32 specimens) across 10 Mycobacterium species were identified. The most frequently isolated NTM species were $M$. intracellulare ( $n=236,54.1 \%)$, followed by M. abscessus $(n=106,24.3 \%)$, M. kansasii $(n=46,10.6 \%)$, M. avium $(n=36,8.3 \%)$. Twenty-two cases had $M$. intracellulare and $M$. abscessus mixed infection and ten cases had M. avium and $M$. abscessus mixed infection. A high level of agreement $(n=696 ; 94.5 \%)$ was found between MGIT 960-TBC ID and PCR-REBA Myco-ID ( $k=0.845, P=0.000)$. PCR-REBA Myco-ID assay had higher AUC for both MTBC and NTM than MGIT 960-TBC ID test.

Conclusion: PCR-REBA Myco-ID has the advantages of rapid, comparatively easy to perform, relatively low cost and superior accuracy in mycobacterial species identification compared with MGIT 960-TBC ID. We recommend it into workflow of mycobacterial laboratories especially in source-limited countries.

Keywords: Mycobacterium tuberculosis (MTB), Nontuberculous mycobacteria (NTM), Identification, PCR-reverse blot hybridization assay (PCR-REBA), Molecular diagnosis

\footnotetext{
*Correspondence: xiaoheping_sars@163.com; 13564641601@163.com

${ }^{2}$ Shanghai Clinic and Research Center of Tuberculosis, Department of Tuberculosis, Shanghai Key Laboratory of Tuberculosis, Shanghai Pulmonary Hospital, Tongji University School of Medicine, No. 507 Zhengmin Road, Shanghai 200433, China

Full list of author information is available at the end of the article
}

C C The Author(s). 2021 Open Access This article is licensed under a Creative Commons Attribution 4.0 International License, which permits use, sharing, adaptation, distribution and reproduction in any medium or format, as long as you give appropriate credit to the original author(s) and the source, provide a link to the Creative Commons licence, and indicate if changes were made. The images or other third party material in this article are included in the article's Creative Commons licence, unless indicated otherwise in a credit line to the material. If material is not included in the article's Creative Commons licence and your intended use is not permitted by statutory regulation or exceeds the permitted use, you will need to obtain permission directly from the copyright holder. To view a copy of this licence, visit http://creativecommons.org/licenses/by/4.0/ The Creative Commons Public Domain Dedication waiver (http://creativecommons.org/publicdomain/zero/1.0/) applies to the data made available in this article, unless otherwise stated in a credit line to the data. 


\section{Background}

The genus Mycobacterium contains a number of acidfast bacilli (AFB), including Mycobacterium tuberculosis complex (MTBC), Mycobacterium leprae, and nontuberculosis mycobacteria (NTM) [1]. NTM are ubiquitous environmental organisms that incidentally cause opportunistic NTM pulmonary disease (NTM-PD) and extrapulmonary infections in immunocompromised individuals [2]. With the prevalence of acquired immunodeficiency syndrome (AIDS), the recognition of clinical importance of NTM is also growing [3]. Recently, many countries have reported a dramatically increased incidence of NTM-PD. [4-7] NTM infections constitutes $0.5-35 \%$ of all human mycobacterial infections [8]. For patients with risk factors, such as bronchiectasis, cystic fibrosis, and immune deficiency, the figure was higher still, over $50 \%$ [9]. However, a high percentage of patients have no risk factors [10]. Infections of most NTM species have been traditionally considered from environmental sources rather than person-to-person transmission like MTBC [11]. In addition, many NTM strains are insensitive to most anti-tuberculosis drugs [12, 13]. Therefore, quality and timely identification of mycobacterium species is necessary for better patient management and appropriate chemotherapy. However, most clinical features (cough, sputum production, fatigue, hemoptysis and fever) and abnormalities on chest radiography (centrilobular nodules, tree-in-bud opacity and cavitation) generally associated with NTM-PD are atypical, which may lead to false diagnoses as PTB, and hence to overtreatment of patients who do not have TB $[14,15]$. The traditional methods used in mycobacterial laboratories require cultivated isolates and the results are only obtained after weeks to months of incubation. Therefore, these culture-based methods are timeconsuming and labor-intensive [16]. Moreover, the traditional methods could not discriminate NTM to the species level, or detect mixed infections in which two or more mycobacterial species were simultaneously detected in the same specimen [17]. All NTM isolates from respiratory samples should be identified at least to species level, since that optimal therapeutic regimen differs according to different species, especially between slowgrowing and rapid-growing species. Therefore, current clinical methods are not conducive to guide clinical decisions in a timely manner. Clinicians sometimes refer only to interferon $-\gamma$ release assays (IGRAs). IGRAs are based on M. tuberculosis specific antigens. These antigens are not present in NTM strains other than $M$. marinum, M. kansasii, M. gordonae and M. szulgai [18]. However, it is worth mentioning that a number of TB patients are also negative in IGRAs [19]. So, IGRAs could not make a reliably distinction between NTM and MTBC.
Advances in molecular assays have accelerated the diagnosis of mycobacteria.

infections over recent years. Among these advances, nucleic acid amplification (NAA)-based techniques permit for identifying mycobacteria at the species level [20-23]. Sequencing of $16 S$ rRNA has been recommended as the gold standard method for definitive identification and discrimination of mycobacterial species [24]. Unfortunately, although fast, some of these techniques still require cultured strains and expensive equipment such as Hain line-probe and minion [22]. A commercial kit based on $16 S$ rRNA sequencing and nucleic acid probes and reverse blot hybridization (REBA), PCR-REBA Myco-ID (Yaneng BioSciences, Shenzhen), was developed for simultaneous genotyping of 22 clinical important mycobacterial species including MTB, $M$. smegmatis, M. Intracellulare, M. kansasii, M. chelonae, M. marinum, M. fortuitum, M. terrae, M. nonchromogenicum, M. avium, $M$. scrofulaceum, $M$. abscessus, $M$. xenopi, M. gilvum, M. phlei, M. triviale, M. gordonae, $M$. gastri, M. vaccae, M. szulgai, M. diernhoferi, M. simiae. Moreover, as a major advantage, PCR-REBA Myco-ID can be performed with clinical specimens. Despite the fact that this technology has been used as a rapid, low cost and easy-to-use method in mycobacterial research works, it has not been incorporated into workflow of many mycobacterial laboratories. Therefore, the purpose of this study was to evaluate clinical applicability of PCR-REBA Myco-ID assay for prompt and accurate identification of NTM at species level directly from 696 clinical specimens in China.

\section{Methods}

Ethics statement and informed consent

This study was approved by The Ethics Committee of the Shanghai Pulmonary Hospital, Tongji University School of Medicine in China (Approval number K20422). Each participant gave written informed consent before enrollment. The study was performed according to the Declaration of Helsinki with respect to ethical principles for research involving application of human specimens.

\section{Clinical specimen collection}

Clinically suspected NTM-PD patients admitted to Shanghai Pulmonary Hospital between January 3, 2018 and November 28, 2019 were eligible for screening if they met the following inclusion criteria: 1) HIV test negative; 2) providing two sputum specimens or bronchial alveolar lavage fluids (BALF) from sputum-scarce patients for MGIT 960-TBC ID test and PCR-REBA Myco-ID test. Samples should be processed within $24 \mathrm{~h}$ of collection. 


\section{Fiberoptic bronchoscopy}

Bronchoscopy procedures were performed as previously described [25].

\section{Routine identification methods}

Nacetyl-L-cysteine (NALC)- $\mathrm{NaOH}$ method was used to decontaminate about $5 \mathrm{ml}$ specimens [26]. The specimens were exposed to $4 \% \mathrm{NaOH}$ for $15-20 \mathrm{~min}$. The sediment was washed with sterile $0.9 \% \mathrm{NaCl}$ solution and resuspended in $1.5 \mathrm{ml}$ sterile $0.9 \% \mathrm{NaCl}$ solution. Two separate $500-\mu \mathrm{l}$ aliquots were prepared in $1.5 \mathrm{ml}$ tubes for MGIT 960-TBc ID test and PCR-REBA MycoID test. Specimens were cultured by MGIT 960 (Becton Dickinson Diagnostic Systems, Sparks, MD) for 6 weeks following the standard procedure of the manufacturer [27]. In order to confirm the presence of mycobacteria and exclude contamination, samples from all positive MGIT 960 tubes were Ziehl-Neelsen (ZN) -stained and Gram-stained. TBc ID (Becton Dickinson, Sparks, MD) is an assay for the detection of MPT64 Ag, a mycobacterial protein secreted by MTBC and certain strains of M. bovis. 100- $\mu$ l liquid media from the positive MGIT tubes was added to the TBc ID card and was incubated for $15 \mathrm{~min}$ at room temperature. The results were visually assessed. A positive test result indicated MTBC and a negative test result indicated NTM.

PCR-reverse blot hybridization assay (PCR-REBA Myco-ID) a) DNA Isolation: $500 \mu \mathrm{l}$ bacterial precipitation was treated with DNA Lysis Buffer $(10 \mathrm{mmol} / \mathrm{L} \mathrm{NaCl}, 1 \mathrm{mg} /$ $\mathrm{ml} \mathrm{SDS}, 0.15 \mathrm{~g} / \mathrm{ml}$ Chelex-1 s00 glass beads, $1 \%$ Tween 20) at $50{ }^{\circ} \mathrm{C}$ for $1 \mathrm{~h}$, then at $100{ }^{\circ} \mathrm{C}$ for $10 \mathrm{~min}$, and centrifuged at $10000 \mathrm{r} / \mathrm{min}$ for $2 \mathrm{~min}$. The supernatant containing genomic DNA was transferred to another tube and preserved at $-20^{\circ} \mathrm{C}$ for further PCR. b) PCR: PCR was carried out in a $50 \mu \mathrm{l}$ reaction mixture including $5 \mu \mathrm{l}$ DNA template, $10 \mathrm{mM}$ Tris/ $\mathrm{HCl}(\mathrm{pH} \mathrm{8.3)}, 50 \mathrm{mM} \mathrm{KCl}$, $2 \mathrm{mM} \mathrm{MgCl} 2,0.2 \mathrm{mM}$ dNTP, $0.4 \mathrm{mM}$ each primer, and $2 \mathrm{U}$ AmpliTaq Gold polymerase. First, the mixture was incubated at $94{ }^{\circ} \mathrm{C}$, to activate the Taq polymerase, followed by 40 cycles of amplification $\left(94^{\circ} \mathrm{C}\right.$ for $1 \mathrm{~min}$, annealing and extension for $30 \mathrm{~s}$ at $65^{\circ} \mathrm{C}, 72^{\circ} \mathrm{C}$ for 1 min), and finally incubated at $72{ }^{\circ} \mathrm{C}$ for $10 \mathrm{~min} .5 \mu \mathrm{l} \mathrm{PCR}$ product was electrophoresed on $6 \%$ polyacrylamide gel with silver staining. c) REBA: The amplified PCR products were REBA tested with Mycobacterium species identification detecting Kit (Yaneng BioSciences, Shenzhen) according to the manufacturer's guidelines. In brief, biotinylated PCR products were denatured at $25^{\circ} \mathrm{C}$ for $5 \mathrm{~min}$ and were added to the REBA membrane strip in the blotting tray provided. Denatured singlestranded PCR products were hybridized with the probes on the strip at $55^{\circ} \mathrm{C}$ for $30 \mathrm{~min}$. The strips were then cleaned twice with gentle shaking in $1.0 \mathrm{ml}$ of washing solution for $10 \mathrm{~min}$ at $55^{\circ} \mathrm{C}$, incubated at $25^{\circ} \mathrm{C}$ for 30 min, and cleaned twice with $1.0 \mathrm{ml}$ of $\mathrm{CDS}$ at room temperature for $1 \mathrm{~min}$. Finally, visualize the signals of colorimetric hybridization and read the band pattern.

\section{PCR-high resolution melting (PCR-HRM) analysis}

To confirm mycobacterium species inconsistently identified by the two different assays, fluorescence PCR-HRM Assay was carried out with Mycobacterium Identification Kit (Zeesan Biotech, Xiamen). The amplification of $r p o B$ gene was performed on the following conditions: preincubation at $95^{\circ} \mathrm{C}$ for $10 \mathrm{~min}$, then denaturation at $95^{\circ} \mathrm{C}$ for $10 \mathrm{~s}, 45$ cycles, annealing for $30 \mathrm{~s}$ at $65^{\circ} \mathrm{C}$, and extension for $10 \mathrm{~s}$ at $72{ }^{\circ} \mathrm{C}$ followed by the $\mathrm{Tm}$ analysis with increasing temperatures from 60 to $95^{\circ} \mathrm{C}$ in a $0.2^{\circ} \mathrm{C} \mathrm{s}-1$ slope increment for $10 \mathrm{~s}$. The HRM analysis was carried out with Gene Scanning Software Version 1.5.0 (Roche Instrument Centre, Switzerland). The aggregation of the melting curves was based on the regions of the melting curve corresponding to the pre-melting, melting, and post-melting regions. Distilled water was used as the non-template control (NTC).

\section{Statistical analysis}

Data analysis was performed using SPSS for Windows (Version 19.0, SPSS Inc., Chicago). All patients were followed up for at least 6 months. The sensitivity, specificity, positive predictive value (PPV), and negative predictive value (NPV) of PCR-REBA Myco-ID assay and MGIT 960-TBc ID test was calculated. The categorical variables were analyzed using Fisher exact or Pearson $X^{2}$ tests where appropriate and 2-tailed tests were used. The concordance of agreement between MGIT 960-TBc ID test and PCR-REBA Myco-ID assay was evaluated using Cohen's kappa test $(k>0.75$, excellent agreement; $0.4<k<0.75$, moderate agreement; and $k<0.4$, poor agreement). Receiver operating characteristic (ROC) curve analysis was performed and the area under curve (AUC) with a 95\% confidence interval (CI) was further calculated. $P<0.05$ was considered statistically significant.

\section{Results \\ Demographic and clinical characteristics of the participants}

In all, 1378 patients (698 sputum and 680 BALF) with clinically suspected NTM-PD were enrolled into this study. Finally, 682 patients were excluded, including 383 patients with obscure diagnosis, 89 patients lost to follow up and 210 patients with non-mycobacterium pulmonary disease (Table 1). The remaining 696 patients (334 sputum and 362 BALF) with mycobacterium pulmonary disease (MPD) (292 MTB and 404 NTM) were eventually analyzed (Fig. 1). Baseline characteristics 


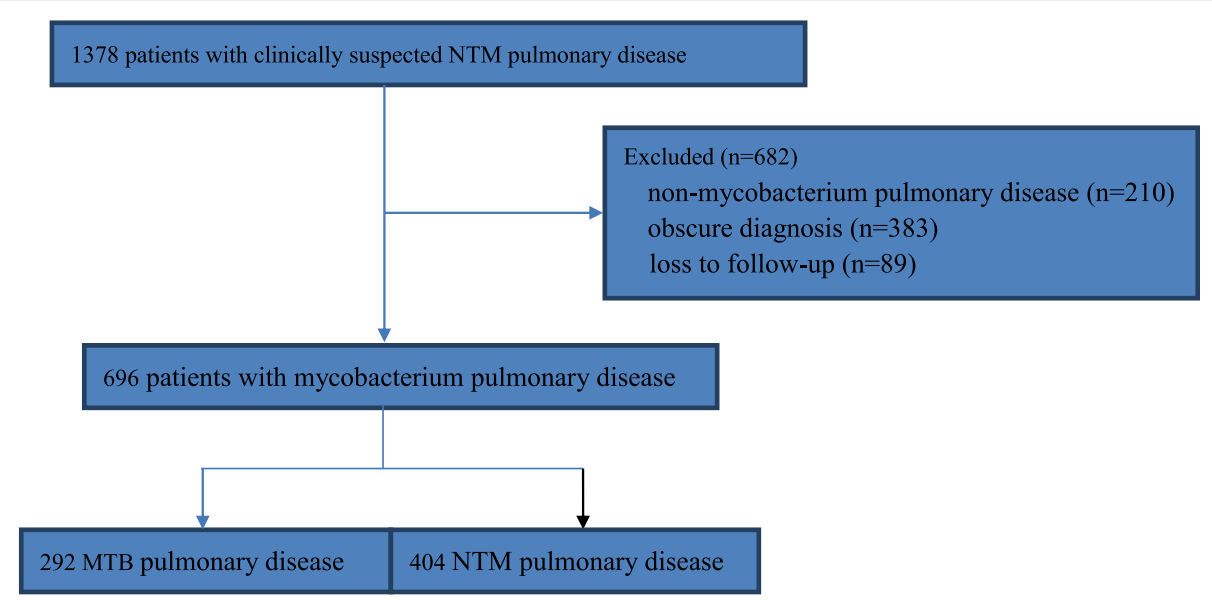

Fig. 1 Flow chart of the study

of the 696 patients were summarized in Table 2. In total, 292 MTBC and 436 NTM isolates (mixed infection of two species in 32 specimens) across 10 Mycobacterium species were identified. The most frequently isolated NTM species were $M$. intracellulare $(n=236,54.1 \%)$, followed by $M$. abscessus $(n=106,24.3 \%), M$. kansasii ( $n=46,10.6 \%)$, M. avium $(n=36,8.3 \%)$, M.scrofulaceum $(n=4,0.9 \%)$, M. phlei $(n=2,0.5 \%)$, M.chelonae $(n=2$, $0.5 \%), M$. xenopi $(n=2,0.5 \%)$, and M. marinum $(n=2$, $0.5 \%)$. Twenty-two patients had $M$. intracellulare and $M$. abscessus mixed infection and ten patients had M. avium and M. abscessus mixed infection (Table 3).

\section{Identification of mycobacterial by MGIT 960-TBC ID}

Of the 292 pulmonary tuberculosis (PTB) patients, 274 isolates (93.8\%) were identified as MTBC and 10 were negative in MGIT 960-TBc ID. Of the 404 NTM-PD patients, 394 isolates $(96.5 \%)$ were identified as NTM and 6 were negative in MGIT 960-TBc ID (Table 4). Since there were two false-positive cases in the non-TB group, the specificity of MGIT 960-TBc ID test for both MTBC and NTM was $99.5 \%$. Eight MTBC were misidentified as NTM, and four NTM misidentified as MTBC.

\section{Identification of mycobacterial by PCR-REBA Myco-ID}

Of the 292 PTB patients, 286 isolates (97.9\%) were identified as MTBC and 6 were negative in PCR-REBA Myco-ID assay. Of the 404 NTM-PD patients, 400 isolates $(99.0 \%)$ were identified as NTM and 4 were negative in PCR-REBA Myco-ID assay. The specificity and PPVs of PCR-REBA Myco-ID assay for both MTBC and NTM were $100 \%$, which were significantly higher than those of MGIT 960-TBC ID $(P=0.04)$. The sensitivity of PCR-REBA Myco-ID to MTBC was also significantly higher than that of MGIT 960-TBC ID $(P=0.012)$.

\section{Consistency between MGIT 960-TBC ID and PCR-REBA Myco-ID}

MGIT 960-TBc ID and PCR-REBA Myco-ID were concordant except for 38 samples (5.5\%) (Table 5). A high level of agreement $(n=696 ; 94.5 \%)$ was found between MGIT 960-TBc ID and PCR-REBA Myco-ID $(k=0.845$,

Table 1 Baseline characteristics of patients with non-mycobacterium pulmonary disease

\begin{tabular}{|c|c|c|c|c|c|}
\hline Condition & Age \pm SD (range) & Gender (male: female) & MGIT $960(+)$ & PCR-REBA (+) & Total (210) \\
\hline Lung cancer & $48 \pm 16(35-80)$ & $49: 38$ & 0 & 0 & 87 \\
\hline Pneumonia & $49 \pm 17(21-78)$ & $35: 30$ & 1(NTM) & 0 & 65 \\
\hline Pulmonary mycosis & $51 \pm 17(35-80)$ & $15: 13$ & 0 & 0 & 28 \\
\hline Silicosis & $48 \pm 8(40-57)$ & $20: 1$ & 0 & 0 & 21 \\
\hline Bronchogenic cyst & $49 \pm 4(45-51)$ & $1: 1$ & 0 & 0 & 2 \\
\hline Interstitial lung disease & $50 \pm 2(48-52)$ & $1: 1$ & 0 & 0 & 2 \\
\hline Pulmonary embolism & $50 \pm 1(49-51)$ & $1: 0$ & $1(\mathrm{MTBC})$ & 0 & 1 \\
\hline Granulomatous vasculitis & 43 & $0: 1$ & 0 & 0 & 1 \\
\hline Right lower lobe sequestration & 46 & $1: 0$ & 0 & 0 & 1 \\
\hline Lung tissue $X$ disease & 51 & $1: 0$ & 0 & 0 & 1 \\
\hline Myelodysplastic syndrome & 45 & $0: 1$ & 0 & 0 & 1 \\
\hline
\end{tabular}


Table 2 Baseline characteristics of patients with mycobacterium pulmonary disease

\begin{tabular}{lll}
\hline & $\begin{array}{l}\text { MTB pulmonary } \\
\text { disease }(\boldsymbol{n}=\mathbf{2 9 2})\end{array}$ & $\begin{array}{l}\text { NTM pulmonary } \\
\text { disease }(\boldsymbol{n}=\mathbf{4 0 4})\end{array}$ \\
\hline Age, SD (range) & $44 \pm 15(25-80)$ & $49 \pm 17(32-86)$ \\
Gender (male: female), $\mathrm{n}$ & $190: 102$ & $191: 213$ \\
Body mass index, median (range) & $19.3(14-29)$ & $19.2(13-28)$ \\
Diabetes mellitus, $\mathrm{n}$ & 32 & 21 \\
Autoimmune diseases, n & 18 & 25 \\
bronchiectasis or cystic fibrosis & 101 & 98 \\
Smear (+) / QFT-GIT ${ }^{\mathrm{a}}(-)$ & 73 & 240 \\
No response to anti-TB & 118 & 66 \\
medication & &
\end{tabular}

QRT-GIT, QuantiFERON-TB Gold In-Tube

$P<0.0001)$, indicating an optimal consistency between the 2 tests. For the 38 strains with inconsistent results of the two methods, PCR-HRM analysis was used for further analysis.

\section{Establishment of ROC curve}

The AUC of PCR-REBA Myco-ID and MGIT 960-TBc ID for MTBC and NTM was 0.990 (95\% CI 0.980-0.999) and 0.964 (95\% CI 0.947-0.982), 0.995 (95\% CI 0.988-1.0) and 0.983 (95\% CI 0.971-0.994) respectively (Figs. 2, 3). PCRREBA Myco-ID had the higher AUC for both MTBC and NTM than MGIT 960- TBC ID.

\section{Discussion}

In current retrospective study, we evaluated the clinical applicability of PCR-REBA Myco-ID assay for rapid detection and differentiation of mycobacterial species directly from respiratory samples (sputum and BALF) in clinically suspected NTM-PD patients. Our results indicate that PCR-REBA Myco-ID assay has higher sensitivity and PPV than MGIT 960-TBC ID, which is consistent with the results of previous study by Lee et al. [28].

Table 3 Identification of clinical isolates using PCR-REBA

\begin{tabular}{lll}
\hline Clinical organism & $\begin{array}{l}\text { Number of } \\
\text { strains (728) }\end{array}$ & $\begin{array}{l}\text { Identified by } \\
\text { PCR-REBA (718) }\end{array}$ \\
\hline MTB & $292(40.1 \%)$ & $286(97.9 \%)$ \\
M. intracellulare & $236(32.4 \%)$ & $232(98.3 \%)$ \\
M. abscessus & $106(14.6 \%)$ & $106(100 \%)$ \\
M. kansasii & $46(6.3 \%)$ & $46(100 \%)$ \\
M. avium & $36(4.9 \%)$ & $36(100 \%)$ \\
M.scrofulaceum & $4(0.5 \%)$ & $4(100 \%)$ \\
M. xenopi & $2(0.3 \%)$ & $2(100 \%)$ \\
M. marinum & $2(0.3 \%)$ & $2(100 \%)$ \\
M. phlei & $2(0.3 \%)$ & $2(100 \%)$ \\
M.chelonae & $2(0.3 \%)$ & $2(100 \%)$ \\
\hline
\end{tabular}

Table 4 Comparison of PCR-REBA and MGIT 960 for Detection of mycobacterium

\begin{tabular}{lllll}
\hline & & PCR-REBA & MGIT 960 & P \\
\hline MTB & sensitivity & $97.9 \%$ & $93.8 \%$ & 0.012 \\
& specificity & $100 \%$ & $99.5 \%$ & 0.317 \\
& PPV & $100 \%$ & $98.6 \%$ & 0.040 \\
& NPV & $98.0 \%$ & $96.7 \%$ & 0.323 \\
\multirow{4}{*}{ NTM } & sensitivity & $99.0 \%$ & $96.5 \%$ & 0.106 \\
& specificity & $100 \%$ & $99.5 \%$ & 0.317 \\
& PPV & $100 \%$ & $98 \%$ & 0.004 \\
& NPV & $99.0 \%$ & $98.5 \%$ & 0.530 \\
\hline
\end{tabular}

Because NTM are ubiquitous in the environment, a single isolated NTM strain from sputum without repeated isolation on culture, is not clinically significant, in general. Therefore, in the investigation of clinically suspected NTM-PD patients, sputum samples should be collected at least two other days for mycobacterium culture. Differentiation of Mycobacteria at the species level by phenotypic and biochemical testing is timeconsuming because of the slow growth rate of mycobacteria. However, the major advantage of some direct molecular detection is to rapidly differentiate MTB from NTM in clinical samples. PCR-REBA Myco-ID assay has a short turnaround time of about $4 \mathrm{~h}$. Timely intervention is also the key to the success of NTM treatment. Another limitation of MGIT 960-TBc ID test is that the accuracy is heavily affected by mycobacterial species and

Table 5 Identification of clinical isolates using PCR-REBA, MGIT 960 and HRM

\begin{tabular}{|c|c|c|c|}
\hline PCR-REBA & MGIT 960 & HRM & Total (696) \\
\hline MTB & $(-)$ & MTB & 10 \\
\hline MTB & NTM & MTB & 8 \\
\hline$(-)$ & MTB & MTB & 6 \\
\hline M.scrofulaceum & MTB & M.scrofulaceum & 4 \\
\hline$(-)$ & NTM & M. intracellular & 4 \\
\hline M. intracellular & $(-)$ & M. intracellular & 2 \\
\hline M. phlei & $(-)$ & M. phlei & 2 \\
\hline M.chelonae & $(-)$ & M.chelonae & 2 \\
\hline MTB & MTB & / & 268 \\
\hline M. intracellulare & NTM & / & 208 \\
\hline M. abscessus & NTM & / & 74 \\
\hline M. kansasii & NTM & / & 46 \\
\hline M. avium & NTM & / & 26 \\
\hline M. xenopi & NTM & / & 2 \\
\hline M. marinum & NTM & / & 2 \\
\hline M. intracellulare-M. abscessus & NTM & / & 22 \\
\hline M. avium-M. abscessus & NTM & / & 10 \\
\hline
\end{tabular}




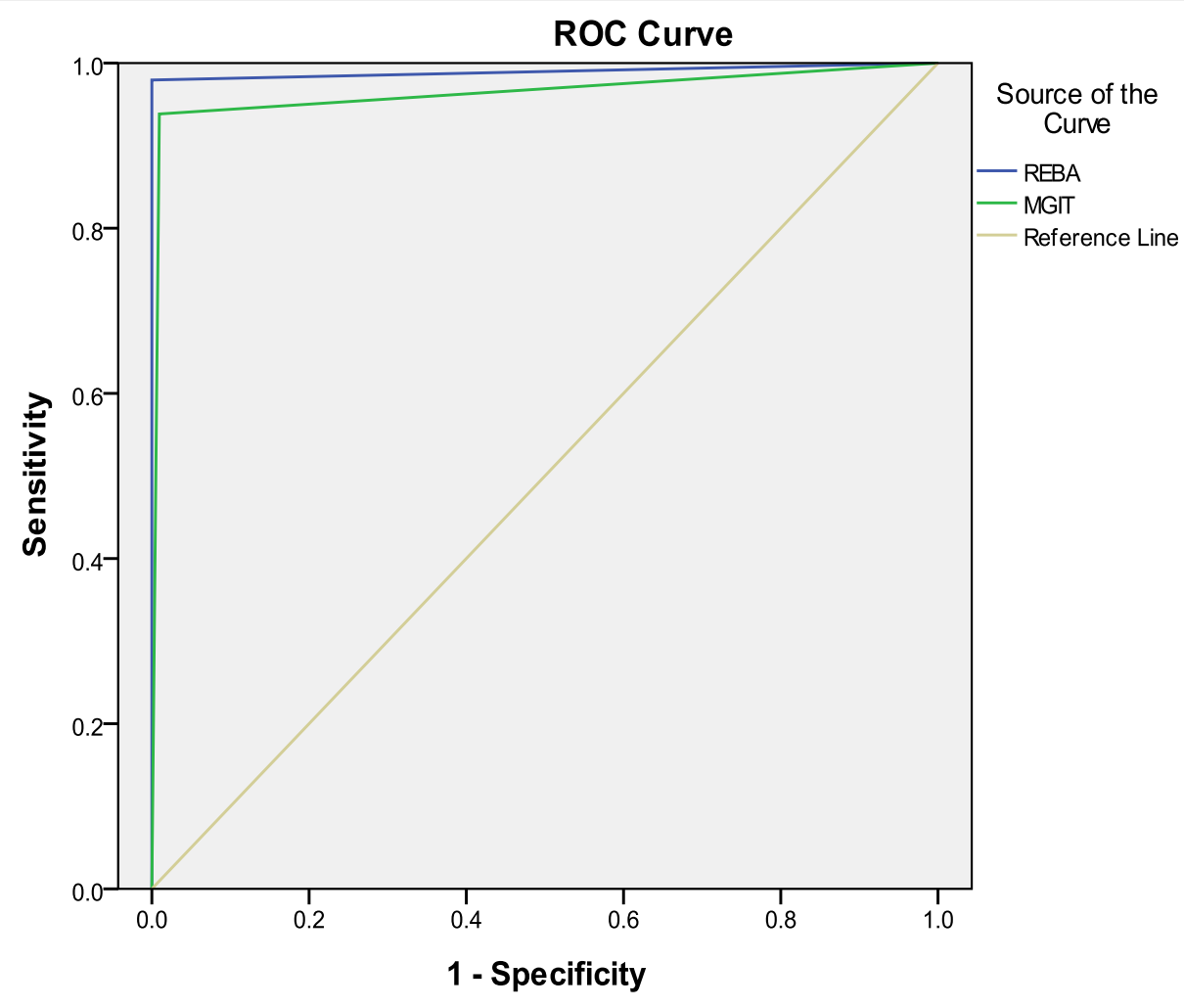

Diagonal segments are produced by ties.

Fig. 2 ROC curve of REBA and MGIT 960 for MTBC

the quality of specimen. Relatively high contamination rate was reported [29]. Our results showed that the overall contamination rate was $1.7 \%(12 / 696)$ in this study. In addition, there were two false positive cultures in the non-TB group including one MTBC and one NTM isolate. Culture of NTM can be difficult even in mycobacterial reference laboratories. For example, while many NTM species grow best at $28^{\circ} \mathrm{C}$ or $45^{\circ} \mathrm{C}$, conventional cultures are performed only at $35^{\circ} \mathrm{C}$. Other NTM species require prolonged incubation or special medium. Some NTM cultivars require supplementary media or extended culture cells. In our current study, six strains of NTM were not cultured, but were detected by PCRREBA Myco-ID assay and confirmed by PCR-HRM analysis. Routinely culture also cannot discriminate NTM species. At present, more than 160 distinct Mycobacterium species have been validly published (http://www. bacterio.net/mycobacterium.html). The clinical relevance of isolated NTM differs strongly by species, from pathogenic species (e.g., Mycobacterium kansasii and Mycobacterium malmoense) to typical saprophytes (Mycobacterium gordonae and Mycobacterium phlei) [30]. In practice, treatment recommendations presented for NTM are based on the NTM species. NTM isolates species should be subspeciated. For example, the prognosis of diseases caused by $M$. intracellulare is better than that caused by M. avium, and the prognosis of diseases caused by $M$. abscessus is worse than that caused by $M$. massiliense [31, 32]. However, PCR-REBA Myco-ID assay cannot further classify $M$. abscessus as M. massiliense, M. bolletii and M. abscessus subspecies. If person-to-person transmission of $M$. abscessus is suspected, it is recommended to use whole genome sequencing (WGS), which has been developed in recent years [33]. Several methods based on WGS achieve subspecies-level resolution [34]. However, this technique is more sophisticated but not cost-effective and requires expensive equipment. It is too expensive to be used routinely in mycobacterial laboratories especially in sourcelimited countries. A limit of this study is that our method was not evaluated using metagenomic data. However, it should be noted that although we investigated 22 clinical important mycobacterial species in clinical samples, PCR-REBA Myco-ID assay appears to include the potential to analyze more NTM species in future studies.

Currently, mass spectrometry (MS) analysis is popular in large hospitals. For its low running costs. However, it was reported that closely related species could not be distinguished correctly [35]. Another limit of MS 


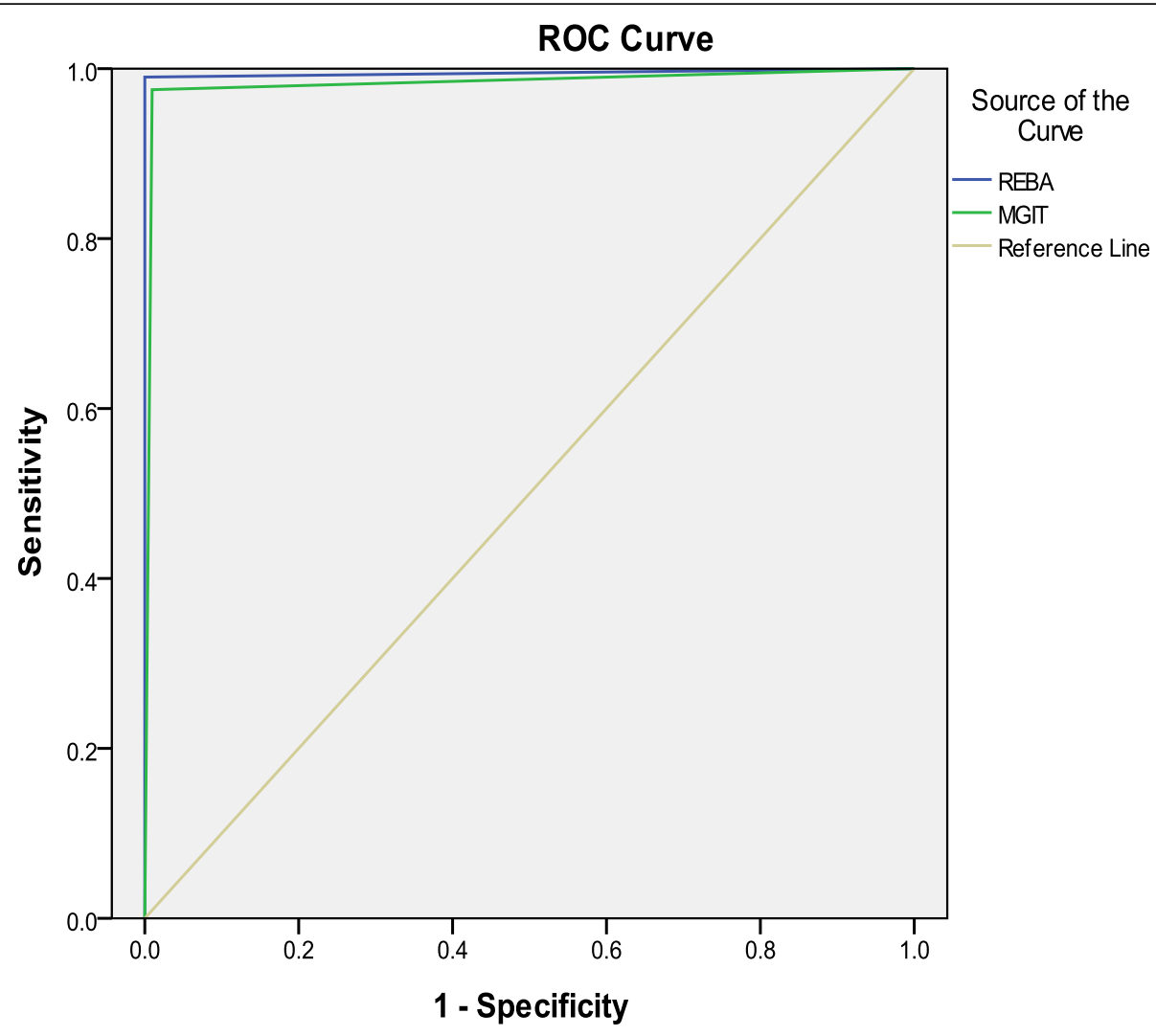

Diagonal segments are produced by ties.

Fig. 3 ROC curve of REBA and MGIT 960 for NTM

analysis is that this method still requires cultured NTM cells similar to Hain Geno Type MTBC test [36]. Polymerase chain reaction (PCR)-restriction fragment length polymorphism (RFLP) analysis (PRA) of some housekeeping genes does not need cultured NTM cells and special expensive equipment. However, PRA cannot discriminate different mycobacterial species in mixed infections [37]. In this study, 22 specimens with $M$. intracellulare and $M$. abscessus mixed infection and 10 specimens with $M$. avium and $M$. abscessus mixed infection were identified by PCR-REBA Myco-ID assay.

\section{Conclusion}

Our finding showed that PCR-REBA Myco-ID assay is an efficient method and has higher specificity and rapidity than conventional methods. Furthermore, it does not require expensive specialized equipment. It should be incorporated into workflow of mycobacterial laboratories especially in source-limited countries.

\section{Abbreviations}

AFB: Acid-fast bacilli; AUC: Area under curve; BALF: Bronchial alveolar lavage fluids; HIV: Human immunodeficiency virus; HRM: High resolution melt analysis; MPD: Mycobacterium pulmonary disease; MTBC: Mycobacterium tuberculosis complex; NAATs: Nucleic acid amplification tests; NPV: Negative predictive value; NTM: Non- tuberculos mycobacteria; PCR-REBA: PCR-reverse blot hybridization assay; PPV: Positive predictive value; PTB: Pulmonary tuberculosis; ROC: Receiver operating characteristic; TB: Tuberculosis; IGRAs: Interferon- $\gamma$ release assays; WHO: World Health Organization

\section{Acknowledgements}

We thank all participants for their time and efforts.

\section{Authors' contributions}

LY, QZ and HX were responsible for the conception and design of the study. LY, QZ and HX were responsible for acquisition and analysis of data; furthermore, LY was in charge of statistical analysis. LY took part in drafting the manuscript; $L Y, Q Z$ and $H X$ revised and approved the final version of the manuscript. All authors read and approved the final submitted version.

\section{Funding}

This work was supported by a grant from the 13th Five-Year National Science and Technology Major Project for Infectious Diseases (Grant

No.2018ZX10722-302). The funders had no role in study design, data collection and analysis, decision to publish, or preparation of the manuscript.

\section{Availability of data and materials}

All data generated or analyzed during this study are included in this published article. The datasets used and/or analyzed during the current study are available from the corresponding author on reasonable request.

\section{Declarations}

Ethics approval and consent to participate

This study was approved by The Ethics Committee of the Shanghai Pulmonary Hospital, Tongji University School of Medicine in China (Approval 
number K20-422). Each participant gave written informed consent before enrollment. The study was performed according to the Declaration of Helsinki with respect to ethical principles for research involving application of human specimens.

\section{Consent for publication}

Not applicable.

\section{Competing interests}

The authors declare that they have no competing interests.

\section{Author details}

${ }^{1}$ Clinic and Research Center of Tuberculosis, Department of Tuberculosis, Shanghai, Key Laboratory of Tuberculosis, Shanghai Pulmonary Hospital, Tongji University School of Medicine, Shanghai, China. ${ }^{2}$ Shanghai Clinic and Research Center of Tuberculosis, Department of Tuberculosis, Shanghai Key Laboratory of Tuberculosis, Shanghai Pulmonary Hospital, Tongji University School of Medicine, No. 507 Zhengmin Road, Shanghai 200433, China.

\section{Received: 16 May 2020 Accepted: 25 February 2021}

Published online: 16 March 2021

\section{References}

1. Bottai D, Stinear TP, Supply P, Brosch R. Mycobacterial pathogenomics and evolution. Microbiol Spectr. 2014;2:MGM2-0025-2013. https://doi.org/10.112 8/microbiolspec.MGM2-0025-2013.

2. Yu X, Liu P, Liu G, Zhao L, Hu Y, Wei G, Luo J, Huang $H$. The prevalence of non-tuberculous mycobacterial infections in mainland China: systematic review and meta-analysis. J Infect. 2016;73:558.

3. Steinbrook R. Tuberculosis and HIV in India. N Engl J Med. 2007:356:1198-9.

4. Donohue MJ, Wymer L. Increasing prevalence rate of nontuberculous mycobacteria infections in five states, 2008-2013. Ann Am Thorac Soc. 2016; 13:Annals ATS.201605-3530C

5. Donohue MJ. Increasing nontuberculous mycobacteria reporting rates and species diversity identified in clinical laboratory reports. BMC Infect Dis. 2018;18:163

6. Hoefsloot W, van Ingen J, Andrejak C, et al. The geo- graphic diversity of nontuberculous mycobacteria isolated from pulmonary samples: an NTMNET collaborative study. Eur Respir J. 2013;42:1604-13.

7. Namkoong H, Kurashima A, Morimoto K, et al. Epidemiology of pulmonary nontuberculous mycobacterial disease, Japan1. Emerg Infect Dis. 2016:22: $1116-7$.

8. González SM, Cortés AC, Yoldi LAS, García JMG, Álvarez LMA, Gutiérrez JJP, en representación de la Red de Laboratorios de Microbiología del SESPA. Non-tuberculous mycobacteria. An emerging threat? Arch Bronconeumol. 2017;53(10):554-60.

9. Prevots DR, Shaw PA, Strickland D, et al. Nontuberculous mycobacterial lung di sease prevalence at four integrated health care delivery systems. Am J Respir Crit Care Med. 2010;182:970-6.

10. Mirsaeidi M, Farshidpour M, Allen MB, Ebrahimi G, Falkinham JO. Highlight on advances in nontuberculous mycobacterial disease in North America. Biomed Res Int. 2014; https://doi.org/10.1155/2014/919474.

11. Falkinham JO. Epidemiology of infection by nontuberculous mycobacteria. Clin Microbiol Rev. 1996;9:177-215.

12. Frieden TR, Sterling TR, Munsiff SS, Watt CJ, Dye C. Tuberculosis. Lancet. 2003;362:887-99.

13. Stout JE, Koh WJ, Yew WW. Update on pulmonary disease due to nontuberculous mycobacteria. Int J Infect Dis. 2016;45:123-34.

14. Wang HX, Yue J, Han M, Yang JH, Gao RL, Jing LJ, Yang SS, Zhao YL. Nontuberculous mycobacteria: susceptibility pattern and prevalence rate in Shanghai from 2005 to 2008. Chin Med J. 2010;123:184-7.

15. Thanachartwet $V$, Desakorn V, Duangrithi D, Chunpongthong $P$, Phojanamongkolkij K, et al. Comparison of clinical and laboratory findings between those with pulmonary tuberculosis and those with nontuberculous mycobacterial lung disease. Southeast Asian J Trop Med Public Health. 2014:45:85-94.

16. Springer B, Stockman L, Teschner K, Roberts GD, Bottger EC. Two-laboratory collaborative study on identification of mycobacteria: molecular versus phenotypic methods. J Clin Microbiol. 1996;34:296-303.

17. van Ingen J. Diagnosis of nontuberculous mycobacterial infections. Sem Respir Crit Care Med. 2013;34:103-9 https://doi.org/10.1055/s-0033-1333569.
18. Ewer K, Deeks J, Alvarez L, et al. Comparison of T-cell-based assay with tuberculin skin test for diagnosis of Mycobacterium tuberculosis infection in a school tuberculosis outbreak. Lancet. 2003;361:1168-73.

19. Dai $Y$, Feng $Y, X u R, X u$ W, Lu W, Wang J. Evaluation of interferon-gamma release assays for the diagnosis of tuberculosis: an updated meta-analysis. Eur J Clin Microbiol Infect Dis. 2012;31:3127-37.

20. Chae H, Han SJ, Kim SY, Ki CS, Huh HJ, Yong D, Koh WJ, Shin SJ. Development of a one-step multiplex PCR assay for differential detection of major Mycobacterium species. J Clin Microbiol. 2017;55:2736.

21. Lim JH, Kim CK, Bae MH. Evaluation of the performance of two real-time PCR assays for detecting Mycobacterium species. J Clin Lab Anal. 2019;33: e22645.

22. Matsumoto $Y$, Kinjo T, Motooka D, Nabeya D, Jung N, Uechi K, Horii T, lida T, Fujita J, Nakamura S. Comprehensive subspecies identification of 175 nontuberculous mycobacteria species based on 7547 genomic profiles. Emerg Microbes Infect. 2019:8:1043-53 https://doi.org/10.1080/22221751.2019.1637702.

23. Parsons M, Somoskövi Á. Laboratory diagnosis of tuberculosis in resourcepoor countries. Clin Microbiol Rev. 2011;24:314-50.

24. Springer B, Bottger EC, Kirschner P, Wallace RJ Jr. Phylogeny of the Mycobacterium chelonae-like organism based on partial sequencing of the 165 rRNA gene and proposal of Mycobacterium mucogenicum sp. nov. Int Syst Bacteriol. 1995:45:262-7 https://doi.org/10.1099/00207713-45-2-262.

25. Yan $\mathrm{L}$, Zhang $\mathrm{Q}$, Xiao $\mathrm{H}$. Clinical diagnostic value of simultaneous amplification and testing for the diagnosis of sputum-scarce pulmonary tuberculosis. BMC Infect Dis. 2017;17:545.

26. Pfyffer GE, Brown-Elliot BA, Wallace RJ. General characteristics, isolation, and staining procedures. In: Murray PR, Baron EJ, Jorgensen JH, Pfaller MA, Yolken $\mathrm{RH}$, editors. Manual of clinical microbiology. 8th ed. Washington, DC: ASM Press; 2003. p. 532-59.

27. Bactec MGIT. 960 system user's manual. Sparks (Maryland): Becton, Dickenson, and Company.

28. Wang H-Y, Kim H, Kim S, Bang H, Kim D-K, Lee H. Evaluation of PCR-reverse blot hybridization assay for the differentiation and identification of Mycobacterium species in liquid cultures. J Appl Microbiol. 2014;118:142-51.

29. Chihota VN, Grant AD, Fielding K, Ndibongo B, van Zyl A, Muirhead D, Churchyard GJ. Liquid vs. solid culture for tuberculosis: performance and cost in a resource-constrained setting. Int J Tuberc L ung Dis. 2010;14:1024-31.

30. van Ingen J, Bendien SA, de Lange WC, Hoefsloot W, Dekhuijzen PN, Boeree MJ, van Soolingen D. Clinical relevance of non-tuberculous mycobacteria isolated in the Nijmegen-Arnhem region, The Netherlands. Thorax. 2009;64: 502-6 https://doi.org/10.1136/thx.2008.110957.

31. Boyle DP, Zembower TR, Reddy S, et al. Comparison of clinical features, virulence, and relapse among mycobacterium avium complex species. Am J Respir Crit Care Med. 2015:191:1310-7.

32. Haworth CS, Banks J, Capstick T, et al. British Thoracic Society guidelines for the management of non-tuberculous mycobacterial pulmonary disease (NTM-PD). Thorax. 2017;72:ii1-ii64.

33. Votintseva AA, Bradley P, Pankhurst L, et al. Same-day diagnostic and surveillance data for tuberculosis via whole-genome sequencing of direct respiratory samples. J Clin Microbiol. 2017:55:1285-98.

34. Zolfo M, Tett A, Jousson O, et al. MetaMLST: multi- locus strain-level bacterial typing from metagenomic samples. Nucleic Acids Res. 2016;1:1-10.

35. Lecorche E, Haenn S, Mougari F, et al. Comparison of methods available for identification of Mycobacterium chimaera. Clin Microbiol Infect. 2018;24 409-13.

36. Loiseau C, Brites D, Moser I, Coll F, Pourcel C, Robbe-Austerman S, Köser CU. Revised interpretation of the Hain Lifescience GenoType MTBC to differentiate Mycobacterium canettii and members of the Mycobacterium tuberculosis complex. Antimicrob Agents Chemother. 2019:63:e00159-19.

37. Lebrun L, Weill FX, Lafendi L, Houriez F, Casanova F, Gutierrez MC, Ingrand $D$, Lagrange $P$, et al. Use of the INNO-LiPA-MYCOBACTERIA assay (version 2) for identification of Mycobacterium avium- Mycobacterium intracellulareMycobacterium scrofulaceum complex isolates. J Clin Microbiol. 2005;43: 2567-74

\section{Publisher's Note}

Springer Nature remains neutral with regard to jurisdictional claims in published maps and institutional affiliations. 